\title{
Preliminary Assessment of the Morphometric and Hydrological Properties of Six Watersheds in the Eastern Part of East Java
}

\author{
Indarto ${ }^{1,}$, Entin Hidayah ${ }^{2}$ \\ ${ }^{1}$ Departemen Agricultural Technology, Faculty of Agricultural Technologi, Universitas Jember, Jl. \\ Kalimantan No: 37 Kampus Tegalboto Jember 68121, Jawa Timur, Indonesia \\ ${ }^{2}$ Departemen Civil Engineering, Faculty of Engineering, Universitas Jember, Jl. Kalimantan No: 37 \\ Kampus Tegalboto Jember 68121, Jawa Timur, Indonesia \\ *) Corresponding Author (email: indarto.ftp@unej.ac.id)
}

Received: 17 March 2019 / Accepted: 02 August 2019 / Published: 03 August 2019

\begin{abstract}
The hydrological process on watersheds is driven by rainfall acting as the input. Physical properties also affect the extent of the response of the watershed to produce runoff. This paper presents the identification, assessment and visualisation of the morphometric and hydrological properties of six watersheds in the eastern part of East Java. Physical characteristics were obtained by cropping the GISlayer with a watershed, while the topographic and morphometric properties of the watersheds were derived from ASTER G-DEM2. In addition, hydrological properties were derived statistically by analysing available rainfall and discharge data; hydrological data (rainfall and discharge) are available for the period 1996 to 2014. Finally, simple statistical analysis by plotting the obtained values was employed to interpret the relationship between the morphometric and hydrological properties of the watersheds. The results show the quantitative number (unit) to describe these properties of the six watersheds that can be used for watershed classification.
\end{abstract}

Keywords: assessment, hydrological, morphometric, properties, watersheds.

Abstrak. Proses hidrologi di dalam suatu DAS dipengaruhi oleh besarnya hujan yang masuk ke dalam DAS. Karakteristik fisik DAS juga mempengaruhi besar kecil nya respon hidrologi DAS dalam menghasilkan aliran permukaan. Artikel ini memaparkan identifikasi, penilaian dan visualisasi sifat morfometrik dan hidrologis daerah aliran sungai (DAS). Enam (6) DAS di bavian timur dari Jawa Timur digunakan untuk analisis. Karakteristik fisik diperoleh dengan memotong lapisan GIS dengan batas DAS. Kemudian ASTER G-DEM2 digunakan untuk menurunkan sifat topografi dan morfometrik daerah aliran sungai. Selain itu, sifat hidrologis diturunkan secara statistik dengan menganalisis data curah hujan dan debit yang tersedia. Data hidrologi (curah hujan dan debit) tersedia dari tahun 1996 - 2014. Akhirnya, analisis statistik sederhana dengan memplot nilai yang diperoleh digunakan untuk menginterpretasikan hubungan antara sifat morfometrik dan hidrologis dari daerah aliran sungai. Hasilnya menunjukkan angka kuantitatif (unit) untuk menggambarkan sifat morfometrik dan hidrologi dari enam DAS yang dapat digunakan untuk klasifikasi DAS.

Kata kunci: penilaian, hidrologi, morfometrik, properti, daerah aliran sungai.

\section{Introduction}

Some hydrological models consider and count the physical properties of watersheds (i.e., soil layers, topography, land use and morphometrics) to calculate the run-off produced by rainfall events. One approach is elaborated by classifying watershed properties in a specific manner. This is done by by selecting similar properties of the watersheds and grouping them 
into categories (classes). However, nature is naturally heterogeneous or diversified and it is probably impossible to find two watersheds that are $100 \%$ similar. Nevertheless, some level of variability could be assumed to be similar using certain criteria. Some similarities amongst watersheds may exist in the form of physical, morphometric or hydrological properties. The similarity approach can be used to compare and evaluate watersheds properties, and the similarity concept can also be integrated into the modelling process. Furthermore, by considering the similarity concept, the hydrological process of watersheds can be identified. The physical properties of watersheds consist of form and size, river network, topography, land use, soil and geological layers. Each property is likely to have a substantial impact on run-off production or the rainfall process. Researchers have quantified some of these properties and included them in the modelling process.

Morphometric properties resume the quantitative relation between topography and river networks on the watershed. Interaction among morphometrics, land use and soil layers determines the watershed response when rainfall events occur. Morphometric properties can be used to conduct analysis of groundwater resource potential and to manage the watershed. Many hydrological phenomena have a significant correlation with form and area, slope, drainage density, and other watershed properties. Runoff produced on the watershed also depends on the structure and properties of the river morphometrics and catchment area. Generally, morphometric analysis uses the linear, area and relief aspects of the river network and watershed slope to derive parameters (Pande and Moharir, 2015)from the study, it is concluded that remote sensing data (SRTM-DEM data of $30 \mathrm{~m}$ resolution.

Thanks to the advances in GIS, the digital elevation model (DEM), hydro-informatics and remote sensing technology, more morphometrical and other related parameters (such as bifurcation ratio, drainage density, slope factor and soil wetness-index) can be derived automatically. Generally, the input for morphometrical analysis is DEM, which is widely available from many suppliers. For specific resolutions, DEM can be downloaded directly from the develop's website; for example, the ASTER Global Digital Elevation Model (GDEM) v2, which is is a product of NASA and METI. It is available at $30 \mathrm{~m}$ pixel resolution can be downloaded from (https:// asterweb.jpl.nasa.gov/gdem.asp).

The DEM Nasional or DEMNAS (http:// tides.big.go.id/DEMNAS/ ) provides resolution finer than Aster GDEM2; it was developed from many data sources, for example IFSAR (pixel resolution $=5 \mathrm{~m}$ ), TERRASAR-X (pixel resolution $=5 \mathrm{~m}$ ) and ALOS PALSAR (pixel resolution $=$ $11.25 \mathrm{~m}$ ). Masspoint data from stereo-plotting is integrated to produce DEMNAS. The spatial resolution of DEMNAS is 0.27-arcseconds, using vertical data of EGM2008. A DEM can also be produced by the interpolation method from topographical input data, such as the work initiated by Indarto, et al., (2009).

Furthermore, DEM is used as an input to determine the watershed boundaries, river network, morphometric parameters, and other indicators relevant to the topography and terrain, hydrology and soil, such as in the work of Tarboton et al., 1991. This function is facilitated by various GIS and remote sensing software, such as the Terrain Analysis System (TAS) (Lindsay, 2005) and its successor, Whitebox_GAT (Lindsay, 2016). Other geoscientific software such as SAGA (Conrad et al., 2015) (http://saga-gis.org/en/index. $\mathrm{html}$ ) provides a more detailed function to derive morphometric, terrain and related soiltopographical parameters. Orfeo geoscientific software (https://www.orfeo-toolbox.org/) also provides similar functionality. Both Orfeo and SAGA have been integrated into open source GIS platforms such as Quantum GIS (QGIS) (https://qgis.org/en/site/) and GRASS (https://qgis.org/en/site/). Commercial GIS software (such as ArcGIS) provides a standard hydrological function that can be used to conduct similar tasks. Table 1 lists the 18 morphometric parameters derived from previous studies (Khare et al., 2014). 
Table 1. Morphoetric parameters, adopted from Khare et al. (2014)

\begin{tabular}{|c|c|c|c|}
\hline \multirow[t]{2}{*}{ No } & $\begin{array}{l}\text { Morphometric } \\
\text { Parameter }\end{array}$ & Description & References \\
\hline & \multicolumn{3}{|l|}{ Linear Aspect } \\
\hline 1 & Stream order $(\mathrm{U})$ & Hierarchical order & Strahler, 1964 \\
\hline 2 & Stream length $(\mathrm{Lu})$ & Length of the stream & Horton, 1933 \\
\hline 3 & $\begin{array}{l}\text { Mean stream length } \\
(\mathrm{Lsm})\end{array}$ & $\begin{array}{l}L s m=L u / N u, \text { where } L u=S t r e a m \text { length of order; } \\
\text { ' } U \text { ' } 1=\text { Stream length of next lower order. } 1=\text { Stream } \\
\text { length of next lower order. }\end{array}$ & Horton, 1933 \\
\hline 4 & Stream length ratio $(\mathrm{Rl})$ & $\begin{array}{l}R l=L u / L u-1, \text { where } L u=\text { Total stream length of } \\
\text { order ' } U \text { ' } L u-L u=\text { Total stream length of order } \\
\text { ' } U \text { ', } 1=\text { Stream length of next lower order. }\end{array}$ & Horton, 1933 \\
\hline \multirow[t]{2}{*}{5} & Bifurcation ratio $(\mathrm{Rb})$ & $\begin{array}{l}R b=N u / N u+1 ; \text { where } N u=\text { Total number of } \\
\text { stream segments of order' } u^{\prime} ; N u+1=\text { Number of } \\
\text { segmenst of next higher order }\end{array}$ & Schumn,1956 \\
\hline & \multicolumn{3}{|l|}{ Relief Aspect } \\
\hline 6 & Basin relief (Bh) & $\begin{array}{l}\text { The vertical distance between the lowest and } \\
\text { highest points of the watershed. }\end{array}$ & Schumn,1956 \\
\hline 7 & Relief ratio $(\mathrm{Rh})$ & $\begin{array}{l}R h=B h / L b \text {; where Bh=Basin relief; } L b=\text { Basin } \\
\text { length }\end{array}$ & Schumn, 1956 \\
\hline \multirow[t]{2}{*}{8} & $\begin{array}{l}\text { Ruggedness number } \\
(\mathrm{Rn})\end{array}$ & $\begin{array}{l}R n=B h \times D d ; \text { where } B h=\text { Basin relief; } \\
D d=\text { Drainage density }\end{array}$ & Schumn, 1956 \\
\hline & Areal Aspect & & \\
\hline 9 & Drainage density (Dd) & $\begin{array}{l}D d=L / A ; \text { where } L=\text { Total length of streams; } \\
A=\text { Area of watershed }\end{array}$ & Horton, 1933 \\
\hline 10 & Stream frequency (Fs) & $\begin{array}{l}F s=N / A ; \text { where } N=\text { Total number of streams; } \\
A=\text { Area of watershed }\end{array}$ & Horton, 1933 \\
\hline 11 & Texture ratio $(\mathrm{T})$ & $\begin{array}{l}T=N 1 / P ; \text { where } N 1=\text { Total number of first-order } \\
\text { streams; } P=\text { Perimeter of watershed }\end{array}$ & Horton, 1933 \\
\hline 12 & Form factor (Rf) & $\begin{array}{l}R f=A /(L b) 2 ; \text { where } A=\text { Area of watershed; } \\
L b=\text { Basin length }\end{array}$ & Horton, 1933 \\
\hline 13 & Circulatory ratio $(\mathrm{Rc})$ & $\begin{array}{l}R c=4 \pi A / P 2 ; \text { where } A=\text { Area of the watershed, } \\
\pi=3.14, P=\text { Perimeter of watershed }\end{array}$ & Miller, 1953 \\
\hline 14 & Elongation ratio $(\mathrm{Re})$ & $\begin{array}{l}R e=2 \sqrt{ }(A / \pi) / L b ; \text { where } A=\text { Area of the watershed, } \\
\pi=3.14, L b=\text { Basin length }\end{array}$ & Schumn,1956 \\
\hline 15 & $\begin{array}{l}\text { Length of overland flow } \\
\text { (Lof) }\end{array}$ & Lof $=1 / 2 D d ;$ where $D d=$ Drainage density & Horton, 1933 \\
\hline 16 & $\begin{array}{l}\text { Constant channel } \\
\text { maintenance ( C ) }\end{array}$ & Lof $=1 / D d ;$ where $D d=$ Drainage density & Horton, 1933 \\
\hline 17 & Index infiltration (IF) & $\begin{array}{l}I F=F S X D D ; \text { where Stream frequency }(F s) \text {, } \\
\text { Drainage density }(D d)\end{array}$ & Horton, 1933 \\
\hline 18 & $\begin{array}{l}\text { Compactness constant } \\
(\mathrm{Cc})\end{array}$ & $\begin{array}{l}C c=0.2821 \times P / A 0.5 ; \text { Where, } A=\text { Area, } P=\text { Basin } \\
\text { perimeter, } \mathrm{km}\end{array}$ & Horton, 1933 \\
\hline
\end{tabular}


These parameters consist of the linear, areal and relief morphometric aspects. The linear aspect considers only one dimensional aspect of morphometric properties (i.e. length). Some examples of a linear aspect of morphometrics are stream order $(\mathrm{U})$, stream length $(\mathrm{Lu})$, mean stream length (Lsm), stream length ratio (RI) and bifurcation ratio $(\mathrm{Rb})$. The areal aspect of morphometrics counts the properties that interact between the linear dimension of the river network and the area dimension of the watershed. Some examples or areal aspects of morphometric properties include drainage density $(\mathrm{Dd})$, stream frequency $(\mathrm{Fs})$, texture ratio $(\mathrm{T})$, form factor $(\mathrm{Rf})$, circulation ratio $(\mathrm{Rc})$, elongation ratio $(\mathrm{Re})$, length of overland flow (lof), constant channel maintenance (C), index infiltration (IF), basin shape (Bs), and compactness constant $(\mathrm{Cc})$. The relief aspect of morphometrics determines the properties that count the interaction between topography and river networks. Examples of relief aspects are basin relief $(\mathrm{Bh})$, relief ratio $(\mathrm{Rh})$ and ruggedness number $(\mathrm{Rn})$.

Early studies by Horton (1933), Horton dan Robert (1945); Hermingler et al. (1993), Miller (1953), Schumn (1956) and Strahler (1964) discuss the importance of each morphometrical parameter for the hydrological processes on the watershed. Further studies conducted by many researchers in India and other parts of the world give examples of how morphometric parameters are derived from RS or GIS Data. Some researchers use morphometrical properties as criteria to determine the priority level for conservation based on morphometric properties (Guth, 2011; Toth, 2013; Rai et al., 2014; Khare et al., 2014; Singh and Singh, 2014;, Umrikar, 2016). The objectives of this study are: (1) to quantify the variability of the morphometric and hydrological properties of the watersheds, and (2) to establish the relationship between these properties.

\section{Research Method}

\subsection{Study Area and Input Data}

The research was conducted at the administrative water boundary of Unit Pelaksana Teknis - Pengelolaan Sumberdaya Air (UPT-PSDA) in Lumajang. Six watersheds were studied, namely Rawatamtu, Mayang, Sanenrejo, Wonorejo, Mujur and Sentul, as shown in Figure 1. Table 2 summarises their main physical properties (i.e. area, perimeter, form, range of altitude and outlet location). With a catchment area range of between $\sim 167.74 \mathrm{~km}^{2}$ to $\sim 700 \mathrm{~km}^{2}$, the watersheds can be classified in three different forms: wide, triangular and elongated. Their elevation ranges between 20 and $3040 \mathrm{~m}$ above sea level.

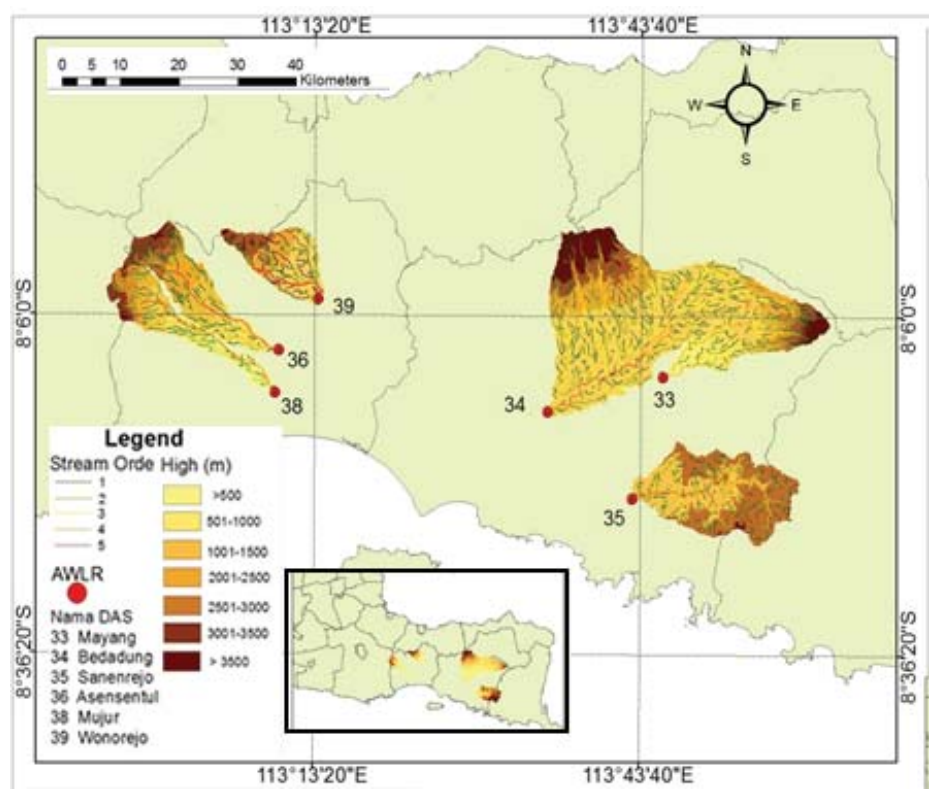

Figure 1. Site location: the six watersheds selected for the study 
Table 2. Main physical properties of the watersheds

\begin{tabular}{lllllll}
\hline \multicolumn{1}{c}{ Form \& Area } & 1_Mayang & 2_Bedadung & 3_Sanenrejo & 4_Mujur & 5_Sentul & 6_Wonorejo \\
\hline Area $\left(\mathrm{km}^{2}\right)$ & 250 & 673 & 275.48 & 137.00 & 186.04 & 177.24 \\
Perimeter $(\mathrm{km})$ & 80,1 & 149 & 83.18 & 88.8 & 100.12 & 81.92 \\
Form & long & Triangle & long & long & wide & wide \\
Altitude (m) & $107-3176$ & $33-3040$ & $20-1207$ & $57-3049$ & $95-2357$ & $60-1569$ \\
Outlet location & & & & & & \\
X-Coord (E) & $113^{0} 76^{\prime} 72^{\prime \prime}$ & $113^{0} 54^{\prime} 00^{\prime \prime}$ & $113^{0} 16^{\prime} 42^{\prime \prime}$ & $113^{0} 23^{\prime} 57^{\prime \prime}$ & $113^{0} 16^{\prime} 42^{\prime \prime}$ & $113^{0} 23^{\prime} 78^{\prime \prime}$ \\
Y-Coord $(\mathrm{S})$ & $8^{0} 18^{\prime} 84^{\prime \prime}$ & $8^{0} 23^{\prime} 23^{\prime \prime}$ & $8^{0} 36^{\prime} 66^{\prime \prime}$ & $8^{0} 21^{\prime} 39^{\prime \prime}$ & $8^{0} 15^{\prime} 25^{\prime \prime}$ & $8^{0} 08^{\prime} 09^{\prime \prime}$ \\
\hline
\end{tabular}

Table 3. Length of recording periods available

\begin{tabular}{lcccccc} 
& 1_Bedadung & 2_Mayang & 3_Sanenrejo & 4_Mujur & 5_Sentul & 6_Wonorejo \\
\hline Discharge & $1996-2014$ & $1996-2011$ & $1996-2001$ & $1996-2013$ & $1996-2013$ & $1996-2014$ \\
\hline Rainfall & $1997-2013$ & $1997-2013$ & $1997-2013$ & $1997-2013$ & $1997-2013$ & $1997-2013$ \\
\hline
\end{tabular}

Seven types of land use dominate the watershed areas: residential use (urban areas), irrigated and non-irrigated paddy, plantation, forest, grass, and other cultivated land. It is noted that in this region the availability of time-series data for hydro-meteorological measurement is generally limited (Table 3).

The daily discharge data from the six outlets over the period 1996 to 2014 were used as input. The length of the data series varies among the watersheds; however, all the available daily discharge data were used for the analysis by assuming that variability due to the different lengths of recording period can be neglected. 136 rainfall measurement sites are located in this region. However, the variability of recording periods varies between 10 to more than 30 years of records. In this case, only selected sites were used for the study. Average daily rainfall data for each watershed were obtained by averaging the daily rainfall data from selected measurement sites located in or close to each watershed boundary. The average daily rainfall data from 1997 to 2013 were then used to describe the characteristics of the rainfall data for each watershed. Furthermore, a DEM for each watershed was extracted from Aster GDEM2 (https:/ / asterweb.jpl.nasa.gov / gdem.asp). The clipped DEM was then used as input to derive the watershed boundary, river network and morphometric properties of the watersheds.

\subsection{Procedures}

\subsubsection{Statistical analysis of hydrological data}

First, the daily flow data from the six outlets were used to derive a statistical resume of the daily discharge data: Maximum, Minimum, Mean, Median and Mean daily baseflow (MDBF), and Percentiles 10, 25, 33, 66, 75, 90 and 95\% (P10, P25, P33, P66, P75, P90, and P95). The mean and median are measures of central tendency. Mean is calculated as the average of the records (the sum of the values/number of days), while the median is the "middle" value of all the records: it is the value exceeded $50 \%$ of the time. For the flow data, the median is usually much lower than the mean daily flow because the distribution of discharge data is negatively skewed, with a lower limit of zero and no upper limit. The percentile value is the value that exceeded a certain percentage of the time. For instance, the $10^{\text {th }}$ percentile is the value that is exceeded by $10 \%$ of the records. The statistical distribution values, i.e: Standard deviation (St_Dev), coefficient of variance $(\mathrm{Cv})$, Kurtosis (Ku), Skewness (Skew), Variability (Var), Standard deviation of the log of daily flows (S_Log), Lane Variability Index 
(Lane), Base Flow Index (BFI) and Flood Flow Index (FFI) were also calculated to represent the hydrological properties of the daily hydrograph. All the values were calculated using the Time Series Module of the River Analysis Package (Marsh, 2003).

Standard deviation (STDev) is a measure of how the values are dispersed from the mean value; it employs the same units as the input data. The coefficient of variation $(\mathrm{Cv})$ is the division of a mean by the standard deviation value. The $\mathrm{Cv}$ of daily flow is the mean of all the daily flow values divided by their standard deviation. Skewness (Skew) is a measure of how different the mean and median are; Skew $=$ mean $/$ median. Skewness can be used to differentiate between catchments with fast and slow storm responses. For a small catchment, the base flow will usually be low, with a dramatic change in discharge during a storm event. Most of the discharge occurs during a storm. However, most days there is low flow. Hence the median flow is low, and the much larger event-based discharges will elevate the mean flow.

As a consequence, the skewness of a small catchment is more important than that of a large one. Similarly, the skewness of an unregulated stream will tend to be higher than that of a regulated stream (depending on the flow release strategy). The measure of variability (Var) used is based on the use of the median as a measure of central tendency. Variability is calculated as the range divided by the median. The user defines the range in terms of the percentile range of flows; the default setting for the range is the difference between the $10^{\text {th }}$ and $90^{\text {th }}$ percentile values.

The standard deviation of the log of daily flows (S_Log) is an estimate of the standard deviation of the logarithm (base 10) of the daily flow values (equation 1). Flow data is often logged to reduce the skew; S_Log is a measure of the distribution of these transformed data, and as such it describes the skew of the input data (Gordon et al., 1992).

$$
S_{\log }=\frac{\log \left(X_{5}\right)-\log \left(X_{95}\right)}{3.29}
$$

where $X 5$ and $X 95$ are the $5^{\text {th }}$ and $95^{\text {th }}$ percentile values respectively

Lane's variability index (Lanes) is described as the standard deviation of the logarithms of the $5^{\text {th }}, 15^{\text {th }}, 25^{\text {th }}, \ldots .85^{\text {th }}$ and $95^{\text {th }}$ percentile values. It is unsuitable for data sets with more than $5 \%$ zero values (i.e. 95 th percentile $=0$ ) or data sets dominated by zeros (Gordon et al., 1992).

Another indicator used in this study is an index of variability (Iv), or slope of flow duration curve (Sfdc). One approach to calculating Sfdc is by using a segment of fdc from percentile 33 $\left(\mathbf{P}_{33}\right)$ to percentile 66( $\left(\mathbf{P}_{66}\right)$, assuming that this segment is relatively linear (McMillan et al., 2016; Pallard, et al., 2009; Taylor et al., 2009). $S f d c$ is then calculated using equation (2).

$$
I v=S f d c=\frac{\ln \left(P_{33}\right)-\ln \left(P_{66}\right)}{(0,66-0,33)}
$$

where :

$\mathrm{S}_{\mathrm{fdc}}=$ slope of FDC,

$\mathrm{Q}_{33 \%}=$ flow at percentile $33 \%$, and

$\mathrm{Q}_{66 \%}=$ flow at percentile $66 \%$.

The steepest slope in the FDC curve shows that the river is subject to high variation in flow regimes. Conversely, a gentle slope in the curve indicates that the flow regime is relatively stable over time (during a year). The stability of the flow regime is formed by the combination of rainfall events that are distributed spatially around the part of the watershed area and the rainfall events that consistently occur during the year. A gentle FDC slope also shows that the contribution of groundwater to the river flow is significant. An example of the use of Sfdc to study river flow regimes was published and applied by Castellarin (2014). Practically, flow duration curve (FDC) analysis has been made using Hydro-office and plotted using Excel. 


\subsubsection{Statistical analysis of rainfall data}

The same analysis was also conducted for daily rainfall data. Average data from each watershed were then entered into RAP to calculate several values of statistical resume and distribution, and monthly and annual rainfall were derived from the daily rainfall data using the Time Series Manager Module (TSM) in RAP. Analysis of the rainfall data was made on RAP to obtain related statistical values. Finally, the statistical values obtained from the analysis of daily discharge and rainfall data were compared between watersheds.

\subsubsection{Morphometric Watershed Analysis}

First, Aster GDEM v2 (http://asterweb. jpl.nasa.gov/GDEM.ASP) was clipped by the watershed boundaries to describe the watershed topography. A series of DEM treatment and watershed delineation was then processed for each watershed. Next, the watersheds areas were derived automatically from the DEM on the top of ArcGIS using the hydrological function. Finally, the main topographical areas of the watersheds were determined automatically from the DEM, and their properties were then compared among the watersheds. Second, the morphometric parameters of each watershed were processed from the DEM using ArcGIS and SAGA (Conrad et al., 2015). Subsequently, 18 morphometric parameters were obtained from these processes (see Table 1). Finally, the morphometric parameters were compared among the watersheds.

\subsection{Interpretation}

Further analysis using a simple statistical method was performed. This was used to find the possible relationships between the hydrological and morphometric parameters using the data from all the watersheds. Simple correlation based on a coefficient of determination was conducted to find the following relationships: (1) between the morphometric parameters; (2) between the discharge and morphometric parameters; (3) between the discharge and rainfall parameters; and (4) between the rainfall and morphometric parameters. In this case, simple statistical criteria based on the value of standard deviation (StDev) and coefficient of variance (Var) were used to identify the level of variability. If the values of StDev and Coef. Var were lower than $\ll 1$, the variability was categorised as "similar", meaning that a certain level of "similarity" existed. Conversely, if the level of variability measured by StDev and Coef. Var was greater than $>>1$, then the variability was categorised as "different". Furthermore, these simple criteria were used to compare both the hydro-meteorological and morphometric parameters. This definition of similarity may be vague in other scientific fields; however, because in hydrology the phenomena always vary in space and time, simplification by classifying the level of variability into a single class called "similar" is useful for practical reasons in order to handle irregularities in hydrology.

\section{Results and Discussion}

\subsection{Hydro-meteorological properties}

\subsubsection{Daily discharge data}

The hydrological properties of the watersheds were represented by the values of the statistical variables, as shown in Table 4. Average discharge for all watersheds was recorded at between 4.25 to $32.84 \mathrm{~m}^{3}$ / day. The maximum daily discharge data ranged from 63 to $1049 \mathrm{~m}^{3}$ / day. Mean daily base flow (MDBF) ranged from 2.77 to $15.18 \mathrm{~m}^{3} /$ day. Each watershed showed variability in terms of daily discharge data, as indicated by the maximum, minimum, mean, median, percentile 10, percentile 90, and MDBF values (Table 4). The distribution of the daily discharge data is also different, as indicated by the values of standard deviation, variance and kurtosis.

Other relatively similar statistical values for the daily discharge data of the watersheds are coefficient of skewness (skew), coefficient of variability (Var), S-Log, Lane's variability index (Lanes), the baseflow index (BFI), the flood flow index (FFI), and the index of variability (Iv). The similarity between BFI and FFI shows 
that these watersheds are located at the same flow regime. Rainy and dry seasons determine the values of average BFI and FFI.

Figure 2 shows the specific FDC properties (Indarto et al., 2016) for each watershed. The FDC for the 38_Mujur and 33_Mayang watersheds are relatively similar. This is also proved by similarity in the form of the two watersheds that are relatively elongated. Such watersheds tend to have a smoother slope of the FDC graphic (not the steepest). This is because runoff from any point of the watershed will arrive in the queue on the outlet.

Among the other watersheds, 35_ Sanenrejo and 34_Bedadung show the steepest slopes in FDC form. This indicates that they are subject to flow regimes characterised by high flow discharges. The two watersheds have a form more widely (between a circle and triangle). Therefore, runoff from any point on the watersheds will probably join the outlet at the same time. The hydrograph will rise more quickly at the time of the high rainfall events.

Table 4. Statistical parameters of daily discharge data

\begin{tabular}{|c|c|c|c|c|c|c|c|c|c|c|}
\hline \multirow[b]{2}{*}{$\begin{array}{c}\text { Stat } \\
\text { Value per } \\
\text { watershed }\end{array}$} & \multirow[b]{2}{*}{ Unit } & \multicolumn{6}{|c|}{ Watershed Identification } & \multicolumn{3}{|c|}{ Qualitative assessment } \\
\hline & & 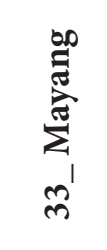 & 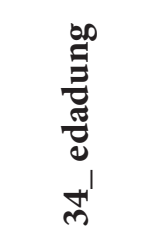 & 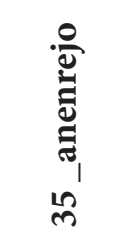 & $\underset{\substack{\prime \\
\underbrace{\prime}}}{\stackrel{B}{\Xi}}$ & $\begin{array}{l}\bar{E} \\
\underset{\Xi}{\Xi} \\
\infty \\
\infty \\
\infty\end{array}$ & 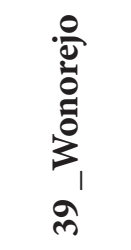 & Mean & StDev & $\begin{array}{c}\text { Qual. } \\
\text { Ass }\end{array}$ \\
\hline Maximum & $\mathrm{m} 3 / \mathrm{s}$ & 70.45 & 1049.00 & 283.00 & 62.40 & 104.00 & 196.06 & 294.15 & 346.28 & different \\
\hline Mean & $\mathrm{m} 3 / \mathrm{s}$ & 4.25 & 32.84 & 10.31 & 4.56 & 9.99 & 16.88 & 13.14 & 9.77 & different \\
\hline Median & $\mathrm{m} 3 / \mathrm{s}$ & 2.97 & 16.00 & 4.84 & 3.98 & 7.19 & 14.80 & 8.30 & 5.19 & different \\
\hline Percentile 10 & $\mathrm{~m} 3 / \mathrm{s}$ & 1.67 & 5.25 & 0.38 & 1.37 & 4.52 & 9.55 & 3.79 & 3.10 & different \\
\hline Percentile 90 & $\mathrm{~m} 3 / \mathrm{s}$ & 8.25 & 77.40 & 26.40 & 8.50 & 14.06 & 25.50 & 26.69 & 23.82 & different \\
\hline $\begin{array}{l}\text { Mean Daily } \\
\text { Baseflow }\end{array}$ & mdbf & 2.77 & 15.18 & 4.25 & 3.28 & 7.35 & 13.03 & 7.64 & 4.83 & different \\
\hline $\begin{array}{l}\text { Standard } \\
\text { Deviation }\end{array}$ & StDEv & 3.83 & 44.98 & 16.21 & 3.27 & 3.30 & 9.61 & 13.53 & 14.81 & different \\
\hline Variance & Var & 14.60 & 2037.30 & 262.60 & 136.40 & 11.00 & 92.30 & 425.70 & 725.68 & different \\
\hline Kurtosis & $\mathrm{Ku}$ & 25.7 & 59.2 & 44.5 & 28.2 & 31.3 & 41.3 & 38.37 & 11.50 & different \\
\hline Skewness & Skew & 3.5 & 5.2 & 4.8 & 5.1 & 3.2 & 4.3 & 4.35 & 0.77 & similar \\
\hline Variability & Var & -1.25 & -2.76 & -2.87 & -1.00 & -0.76 & -0.67 & -1.55 & 0.91 & similar \\
\hline S_Log & S_Log & 0.22 & 0.42 & 0.46 & 0.27 & 0.24 & 0.18 & 0.30 & 0.11 & similar \\
\hline $\begin{array}{l}\text { Lane's } \\
\text { Variability }\end{array}$ & Lanes & 0.22 & 0.44 & 0.49 & 0.24 & 0.22 & 0.17 & 0.30 & 0.12 & similar \\
\hline $\begin{array}{l}\text { Baseflow } \\
\text { Index }\end{array}$ & BFI & 0.65 & 0.46 & 0.41 & 0.72 & 0.74 & 0.77 & 0.63 & 0.14 & similar \\
\hline $\begin{array}{l}\text { Flood Flow } \\
\text { Index }\end{array}$ & FFI & 0.35 & 0.54 & 0.59 & 0.28 & 0.26 & 0.23 & 0.37 & 0.14 & similar \\
\hline $\begin{array}{l}\text { Index } \\
\text { Variability }\end{array}$ & Iv & 0.56 & 0.95 & 0.27 & 0.9 & 0.67 & 1.24 & 0.77 & 0.31 & similar \\
\hline
\end{tabular}




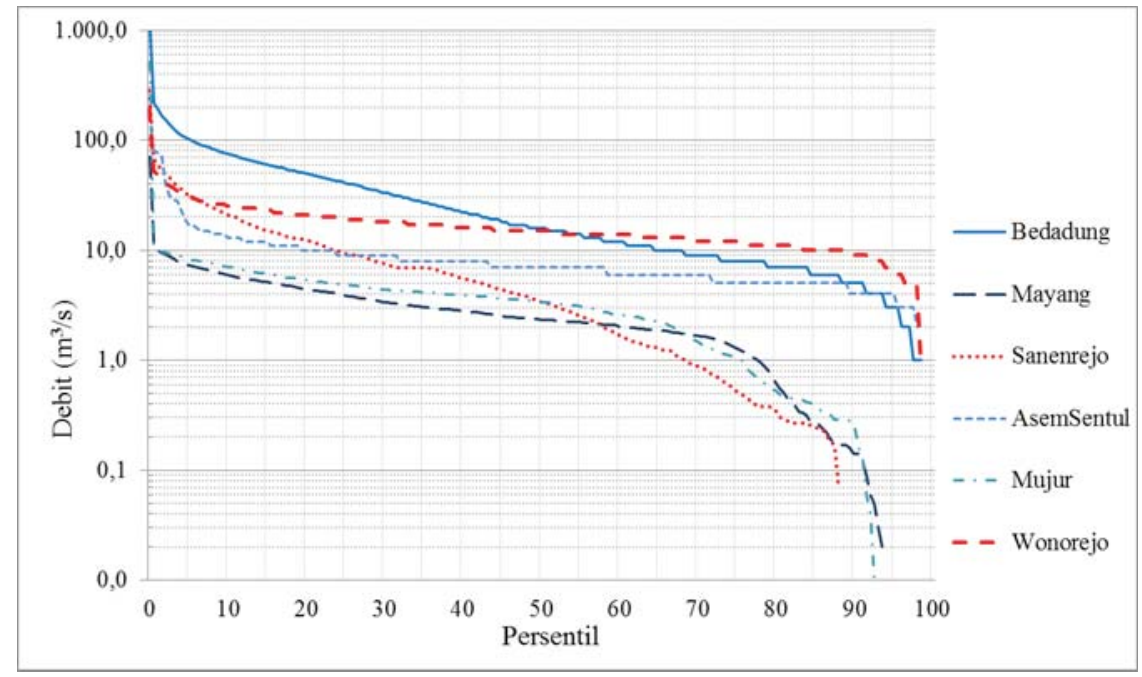

Figure 2. Flow duration curve of the six watersheds

Table 5. Statistical analysis of daily rainfall

\begin{tabular}{|c|c|c|c|c|c|c|c|c|c|c|c|c|}
\hline \multirow{2}{*}{$\begin{array}{c}\text { Statistic } \\
\text { value per } \\
\text { watershed }\end{array}$} & \multicolumn{6}{|c|}{ Watershed Identification } & \multicolumn{5}{|c|}{ Statistical value among watersheds } & \multirow{2}{*}{$\begin{array}{c}\text { Qual. } \\
\text { Assessment }\end{array}$} \\
\hline & & & & & & & Min & $\operatorname{Max}$ & Mean & StDev & Var & \\
\hline Mean & 5.2 & 6 & 4.4 & 5.3 & 5.7 & 5 & 4.40 & 6.00 & 5.27 & 0.51 & 0.26 & Similar \\
\hline Median & 1 & 1.3 & 0 & 0.7 & 1.3 & 1.3 & 0.00 & 1.30 & 0.93 & 0.47 & 0.22 & Similar \\
\hline Std. Dev & 8.7 & 9.4 & 10.1 & 9.2 & 9.7 & 8 & 8.00 & 10.10 & 9.18 & 0.68 & 0.46 & Similar \\
\hline Coef. Var & 1.7 & 1.6 & 2.3 & 1.7 & 1.7 & 1.6 & 1.60 & 2.30 & 1.77 & 0.24 & 0.06 & Similar \\
\hline Skewness & 2.8 & 2.4 & 3.6 & 3.4 & 3.1 & 2.9 & 2.40 & 3.60 & 3.03 & 0.39 & 0.16 & Similar \\
\hline Max & 84.5 & 80.1 & 104.5 & 149.7 & 101 & 99.3 & 80.1 & 149.7 & 103.1 & 22.6 & 511.2 & Different \\
\hline
\end{tabular}

\subsubsection{Daily rainfall data}

Table 5 shows the results of the statistical analysis of the averaged daily rainfall data from the watersheds. In Table 4 , it can be seen that the values of standard deviation (StDev) and variance (Var) of the daily rainfall parameters are lower than $<<$ 1. These values were obtained for statistical resume (i.e. average, mean, median, StDEv, coefficient of variation and skewness). However, the similarity is not evident in extreme rainfall events (i.e. maximum rainfall).

\subsubsection{Monthly rainfall data}

Having a tropical climate, two seasons are distinguishable in this region (rainy and dry seasons). The rainy season occurs from October to April and the dry season normally from May to September (Indarto et al., 2016). The amount of rainfall received during the rainy season is important; more than $70 \%$ of total rainfall is received at this time. Therefore, the amount of rainfall over the year is very varied. This will influence the values of the statistical resume for monthly rainfall (i.e. mean, median, StDev, and Coef Var), as shown in Table 6. The same effect is observed in annual rainfall statistical values (Table 7).

It can be noted from Table 6 and Table 7 that the values of Coef. Var and Skewness are relatively similar among the watersheds. This means that the variability and distribution of rainfall from month to month and year to year are relatively similar. 
Table 6. Statistical values of monthly rainfall data

\begin{tabular}{|c|c|c|c|c|c|c|c|c|c|c|c|c|}
\hline \multirow{2}{*}{$\begin{array}{c}\text { Statistic } \\
\text { value per } \\
\text { watershed }\end{array}$} & \multicolumn{6}{|c|}{ Watershed Identification } & \multicolumn{5}{|c|}{ Statistical values among watersheds } & \multirow{2}{*}{$\begin{array}{c}\text { Qual. } \\
\text { Assesment }\end{array}$} \\
\hline & 33 & 34 & 35 & 36 & 38 & 39 & Min & Max & Mean & StDev & Var & \\
\hline Mean & 157.2 & 179.2 & 125.4 & 157.8 & 193.4 & 150.2 & 125.40 & 193.40 & 160.53 & 21.56 & 464.73 & Different \\
\hline Median & 138.4 & 147.1 & 78.3 & 154.8 & 204.1 & 143.8 & 78.30 & 204.10 & 144.42 & 36.71 & 1347.52 & Different \\
\hline Std. Dev & 141.3 & 163.6 & 126.7 & 114.3 & 127.3 & 112.3 & 112.30 & 163.60 & 130.92 & 17.46 & 304.93 & Different \\
\hline Coef. Var & 0.9 & 0.9 & 1 & 0.7 & 0.7 & 0.7 & 0.70 & 1.00 & 0.82 & 0.12 & 0.01 & Similar \\
\hline Skewness & 0.7 & 0.8 & 0.9 & -0.4 & 0.5 & 0.4 & -0.40 & 0.90 & 0.48 & 0.43 & 0.18 & Similar \\
\hline Max & 594.8 & 678.9 & 560 & 468.3 & 573 & 458.5 & 458.50 & 678.90 & 555.58 & 75.40 & 5685.22 & Different \\
\hline
\end{tabular}

Table 7. Statistical values of annual rainfall data

\begin{tabular}{|c|c|c|c|c|c|c|c|c|c|c|c|c|}
\hline \multirow{2}{*}{$\begin{array}{c}\text { Statistic } \\
\text { value per } \\
\text { watershed }\end{array}$} & \multicolumn{6}{|c|}{ Watershed Identification } & \multicolumn{5}{|c|}{ Statistical values among watersheds } & \multirow{2}{*}{$\begin{array}{c}\text { Qual. } \\
\text { Assesment }\end{array}$} \\
\hline & 33 & 34 & 35 & 36 & 38 & 39 & Min & Max & Mean & StDev & Var & \\
\hline Mean & 1885.8 & 2150.4 & 1505 & 1721.6 & 2321.3 & 1802.9 & 1505.0 & 2321.3 & 1897.83 & 270.08 & 72941.2 & Different \\
\hline Median & 1919.3 & 2187 & 1514.4 & 1661.3 & 2349.6 & 1717.4 & 1514.4 & 2349.6 & 1891.50 & 295.37 & 87242.6 & Different \\
\hline Std. Dev & 289.5 & 461.6 & 374 & 289.5 & 541.7 & 436.5 & 289.5 & 541.7 & 398.80 & 91.55 & 8382.2 & Different \\
\hline Coef. Var & 0.2 & 0.2 & 0.2 & 0.2 & 0.2 & 0.2 & 0.20 & 0.20 & 0.20 & 0.00 & 0.00 & Similar \\
\hline Skewness & 0.4 & 0.6 & -0.9 & 0.4 & -0.7 & 1.6 & -0.90 & 1.60 & 0.23 & 0.84 & 0.70 & Different \\
\hline Min & 1432.3 & 1359.2 & 705 & 1228.7 & 1008 & 1111.2 & 705.00 & 1359.20 & 1140.73 & 241.12 & 58138.4 & Different \\
\hline
\end{tabular}

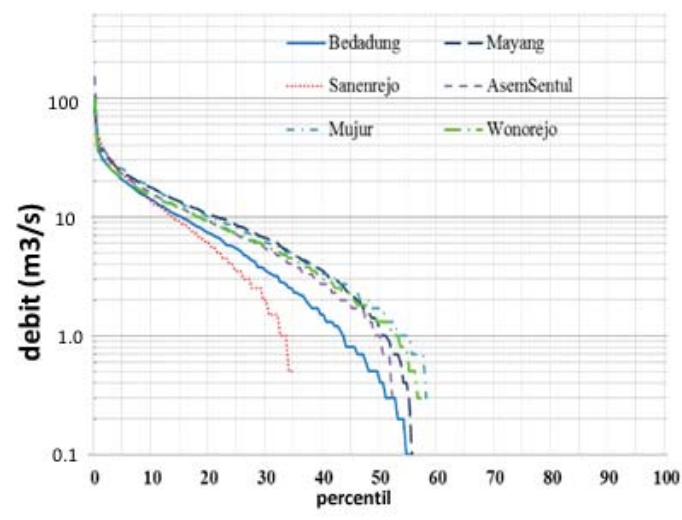

Daily rainfall

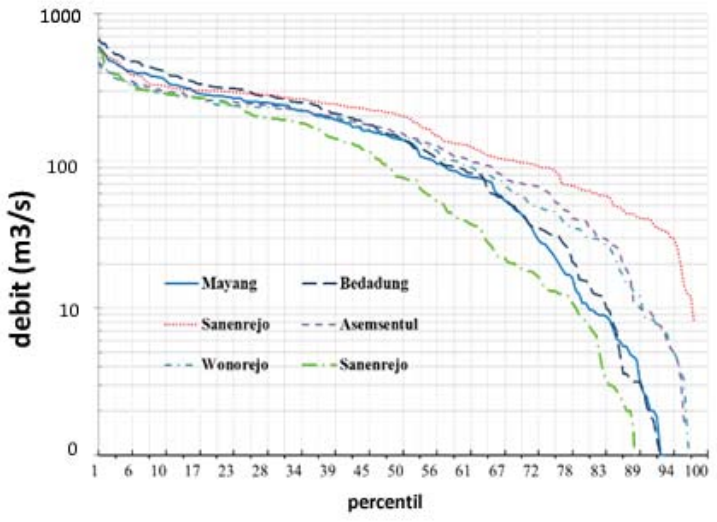

Monthly rainfall

Figure 3. FDC applied to daily and monthly rainfall data

Figure 3 shows the FDC used to plot (a) monthly rainfall, as shown in figure $3 b$, the the daily rainfall and (b) monthly rainfall of individual curves are relatively separate from the watersheds. The individual curves for daily each other. This shows the differences between rainfall data are relatively close to each other, the watersheds in terms of monthly rainfall except for Bedadung and Sanenrejo, while for received. 


\subsection{Morphometric characteristics}

\subsubsection{Linear aspect}

Table 8 presents the results of the statistical analysis of the linear aspect of the morphometric parameters among the six watersheds. By using the same criteria as for the comparison hydrological properties (SdDev and Coef.Var), some morphometric parameters are categorised in a similar way, while others are different.

Table 8. Morphometric parameters - linear aspect of watersheds

\begin{tabular}{|c|c|c|c|c|c|c|c|c|c|c|c|}
\hline 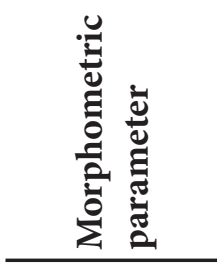 & $\begin{array}{l}\text { a } \\
\text { है } \\
\text { है }\end{array}$ & $\sum_{m}^{\infty 00}$ & 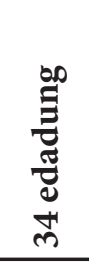 & 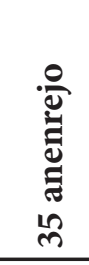 & 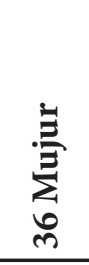 & 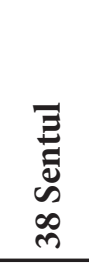 & 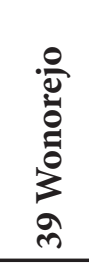 & $\sum_{\tilde{\Sigma}}^{\tilde{\Xi}}$ & 窝 & 8 & 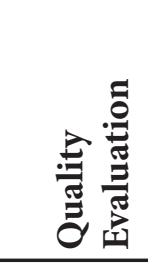 \\
\hline Area & A & 150 & 673 & 292 & 167 & 137 & 132 & 258.5 & 211.6 & 44768.3 & Different \\
\hline Perimeter & $\mathrm{L}$ & 80 & 177 & 94 & 87 & 88.8 & 63 & 98.3 & 40.03 & 1602.2 & Different \\
\hline $\begin{array}{l}\text { Total stream } \\
\text { length }\end{array}$ & TLu & 222.8 & 926 & 285 & 251 & 214 & 190 & 348.13 & 284.9 & 81211.3 & Different \\
\hline $\begin{array}{l}\text { Stream } \\
\text { order }\end{array}$ & $\mathrm{U}$ & 4 & 5 & 4 & 4 & 4 & 4 & 4.17 & 0.41 & 0.167 & Similar \\
\hline $\begin{array}{l}\text { Stream } \\
\text { length }\end{array}$ & $\mathrm{Lu}$ & 30 & 56 & 35 & 33 & 34 & 19 & 34.50 & 12.05 & 145.100 & Different \\
\hline $\begin{array}{l}\text { Bifurication } \\
\text { ratio }\end{array}$ & $\mathrm{Rb}$ & 6.26 & 2.43 & 1.82 & 2.02 & 3.23 & 1.77 & 2.92 & 1.72 & 2.967 & Different \\
\hline $\begin{array}{l}\text { Mean } \\
\text { stream } \\
\text { length }\end{array}$ & Lsm & 1.46 & 1.39 & 0.89 & 1.02 & 0.81 & 1.42 & 1.17 & 0.29 & 0.085 & Identical \\
\hline $\begin{array}{l}\text { Stream } \\
\text { length ratio }\end{array}$ & $\mathrm{Rl}$ & 1.06 & 1 & 1.16 & 1.4 & 0.95 & 1.02 & 1.10 & 0.16 & 0.027 & Identical \\
\hline
\end{tabular}

Table 9. Morphometric parameters - relief aspect of watersheds

\begin{tabular}{|c|c|c|c|c|c|c|c|c|c|c|c|}
\hline 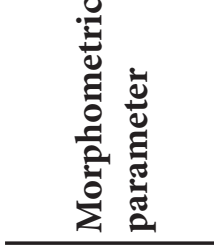 & $\begin{array}{l}\frac{\infty}{0} \\
\text { है } \\
\text { है }\end{array}$ & $\sum_{m}^{\infty}$ & 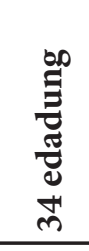 & 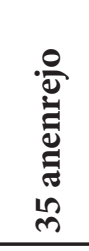 & 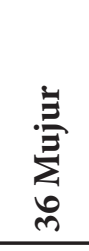 & $\begin{array}{l}E \\
E \\
\tilde{E} \\
\infty \\
\infty \\
\infty\end{array}$ & 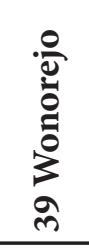 & $\sum_{\Sigma}^{\Xi}$ & 㡍 & 3 & 苞营 \\
\hline Basin Relief & $\mathrm{Bh}$ & 2.61 & 2.74 & 1.17 & 2.64 & 3.61 & 1.63 & 2.40 & 0.87 & 0.757 & Identical \\
\hline Relief Ratio & $\mathrm{Rh}$ & 0.09 & 0.05 & 0.03 & 0.08 & 0.11 & 0.09 & 0.08 & 0.03 & 0.001 & Identical \\
\hline $\begin{array}{l}\text { Ruggedness } \\
\text { Number }\end{array}$ & $\mathrm{Rn}$ & 0.13 & 0.07 & 0.03 & 0.12 & 0.17 & 0.12 & 0.11 & 0.05 & 0.002 & Identical \\
\hline
\end{tabular}


Stream order $(\mathrm{U})$ is similar $(\mathrm{U}=4)$ among five watersheds, with the exception of Bedadung ( $\mathrm{U}=$ 5). Main stream length (Lsm) and stream length ratio (RI) are also similar. Other linear parameters such as stream length $(\mathrm{Lu})$ and bifurcation ratio $(\mathrm{Rb})$ are relatively different among the watersheds.

\subsubsection{Relief aspect}

Table 9 shows the results of the statistical analysis of the relief aspect of the morphometric parameters. It can be seen that all of the three parameters (basin relief $=B h$, relief ratio $=R h$ and ruggedness number $=\mathrm{Rn}$ ) are similar among the watersheds.

\subsubsection{Area aspect}

Table 10 shows the results of the statistical analysis of the area aspect of the watershed morphometric parameters. It can be seen that most of the morphometric parameters (10/11) are categorised in a similar way, namely drainage density (Dd), infiltration index (If), stream frequency $(\mathrm{Fs})$, texture ratio $(\mathrm{T})$, form factor (Rf), circulation ratio (Rc), elongation ratio (Re), length of overland flow (Lof), constant channel maintenance $(\mathrm{C})$, and compactness constant $(\mathrm{Cc})$. Only basin shape (Bs) is different.

It can be concluded that most of the morphometric parameters, including linear, relief and area aspects, are relatively similar amongst the watersheds. A total of 17 out of the 20 morphometric parameters are categorised in a similar way, with only basin shape (Bs), bifurcation ratio $(\mathrm{Rb})$ and stream length $(\mathrm{Lu})$ different.

Table 10. Morphometric parameters - areal aspect of watersheds

\begin{tabular}{|c|c|c|c|c|c|c|c|c|c|c|c|}
\hline 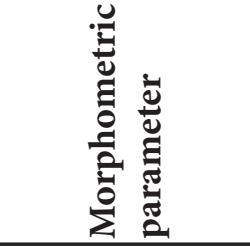 & $\begin{array}{l}\text { क } \\
0 \\
\text { है } \\
\text { है }\end{array}$ & $\sum_{m}^{\infty}$ & 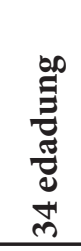 & 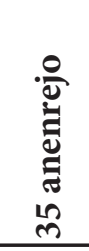 & 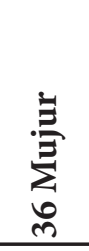 & $\begin{array}{l}\bar{E} \\
\tilde{E} \\
\infty \\
\infty \\
\infty \\
n\end{array}$ & 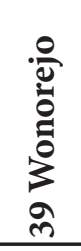 & 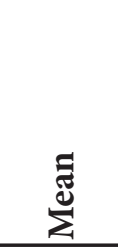 & 窝 & 3 & 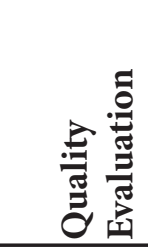 \\
\hline Area & A & 150 & 673 & 292 & 167 & 137 & 132 & 258.5 & 211.6 & 44768.3 & Different \\
\hline Perimeter & $\mathrm{L}$ & 80 & 177 & 94 & 87 & 88.8 & 63 & 98.3 & 40.03 & 1602.2 & Different \\
\hline $\begin{array}{l}\text { Total stream } \\
\text { length }\end{array}$ & $\mathrm{TLu}$ & 222.8 & 926 & 285 & 251 & 214 & 190 & 348.13 & 284.9 & 81211.3 & Different \\
\hline $\begin{array}{l}\text { Stream length } \\
\text { ratio }\end{array}$ & $\mathrm{Rl}$ & 1.06 & 1 & 1.16 & 1.4 & 0.95 & 1.02 & 1.10 & 0.16 & 0.027 & Similar \\
\hline $\begin{array}{l}\text { Drainage } \\
\text { Density }\end{array}$ & $\mathrm{Dd}$ & 1.49 & 1.38 & 0.98 & 1.5 & 1.56 & 1.44 & 1.39 & 0.21 & 0.044 & Similar \\
\hline $\begin{array}{l}\text { Infiltration } \\
\text { Index }\end{array}$ & IF & 1.58 & 1.38 & 1.15 & 2.94 & 2.89 & 1.41 & 1.89 & 0.80 & 0.647 & Similar \\
\hline $\begin{array}{l}\text { Stream } \\
\text { Frequency }\end{array}$ & Fs & 1.06 & 1 & 1.17 & 1.96 & 1.85 & 0.98 & 1.34 & 0.45 & 0.199 & Similar \\
\hline Texture Ratio & $\mathrm{T}$ & 1 & 1.9 & 1.84 & 1.95 & 1.32 & 1.03 & 1.51 & 0.44 & 0.196 & Similar \\
\hline Form Factor & $\mathrm{Rf}$ & 1.39 & 0.21 & 0.24 & 0.15 & 0.12 & 0.37 & 0.41 & 0.49 & 0.237 & Similar \\
\hline $\begin{array}{l}\text { Circulation } \\
\text { Ratio }\end{array}$ & Rc & 0.29 & 0.27 & 0.42 & 0.28 & 0.22 & 0.42 & 0.32 & 0.08 & 0.007 & Similar \\
\hline $\begin{array}{l}\text { Elongation } \\
\text { Ratio }\end{array}$ & $\operatorname{Re}$ & 0.46 & 0.52 & 0.55 & 0.44 & 0.39 & 0.68 & 0.51 & 0.10 & 0.010 & Similar \\
\hline $\begin{array}{l}\text { Length of } \\
\text { Overland Flow } \\
\text { Constant }\end{array}$ & Lof & 0.74 & 0.69 & 0.51 & 0.75 & 0.78 & 0.72 & 0.70 & 0.10 & 0.009 & Similar \\
\hline $\begin{array}{l}\text { Channel } \\
\text { Maintenance }\end{array}$ & $\mathrm{C}$ & 0.67 & 0.73 & 1.02 & 0.67 & 0.64 & 0.69 & 0.74 & 0.14 & 0.020 & Similar \\
\hline Basin Shape & Bs & 6.00 & 4.66 & 4.20 & 6.52 & 8.44 & 2.73 & 5.42 & 2.00 & 3.989 & Different \\
\hline $\begin{array}{l}\text { Compactness } \\
\text { Constant }\end{array}$ & $\mathrm{Cc}$ & 0.31 & 0.15 & 0.19 & 0.30 & 0.37 & 0.28 & 0.27 & 0.08 & 0.007 & Similar \\
\hline
\end{tabular}




\subsubsection{Relationship between morphometric properties}

Table 11 shows a simple analysis using coefficient correlation to establish the relationship between the morphometric properties. The analysis comprises all the morphometric parameters from the watersheds. It is shown that some have a strong correlation with other parameters. For example, area $(\mathrm{A})$, perimeter $(\mathrm{L})$, total stream length $(\mathrm{Tlu})$ the and stream length $(\mathrm{Lu})$ are correlated with each other. A greater watershed area will generate perimeter stream, length and total stream length more important. Furthermore, a similar relationship exists between infiltration index (If), basin relief (Bh), relief ratio (Rh), ruggedness number (Rn), drainage density $(\mathrm{Dd})$, stream frequency (Fs), basin shape (Bs), compactness constant (Cc), and length of overland flow (Lof).

Table 11. Coefficient correlation between morphometric parameters

\begin{tabular}{|c|c|c|c|c|c|c|c|c|c|c|c|c|c|c|c|c|c|c|c|}
\hline & A & $\mathrm{P}$ & LU & NU & LSM & $\mathrm{DD}$ & FS & LOF & $\mathrm{C}$ & $\mathrm{T}$ & $\mathrm{RF}$ & IF & ER & CR & $\mathrm{BH}$ & $\mathrm{RH}$ & $\mathrm{RN}$ & $\mathrm{RB}$ & RL \\
\hline A & 1.00 & $.959^{* *}$ & $\star .975^{\star \star}$ & $+.990^{\star *}$ & -0.44 & -0.28 & 0.09 & -0.28 & 0.20 & $.946^{* *}$ & 0.48 & -0.24 & 0.51 & 0.07 & -0.08 & -0.55 & -0.19 & -0.22 & 0.13 \\
\hline $\mathrm{P}$ & & 1.00 & $.967^{\star \star}$ & t.957** & -0.51 & -0.11 & 0.12 & -0.11 & 0.04 & $.885^{\star}$ & 0.25 & -0.01 & 0.28 & -0.21 & 0.20 & -0.30 & 0.09 & -0.24 & 0.08 \\
\hline LU & & & 1.00 & $.945^{\star *}$ & -0.37 & -0.07 & -0.04 & -0.07 & -0.02 & $.973^{* *}$ & 0.43 & -0.08 & 0.45 & -0.05 & 0.07 & -0.39 & -0.02 & -0.17 & 0.10 \\
\hline $\mathrm{NU}$ & & & & 1.00 & -0.54 & -0.35 & 0.22 & -0.35 & 0.28 & $.894^{\star}$ & 0.42 & -0.22 & 0.45 & 0.04 & -0.08 & -0.55 & -0.19 & -0.29 & 0.09 \\
\hline LSM & & & & & 1.00 & 0.29 & $-.867^{\star}$ & 0.29 & -0.32 & -0.23 & 0.02 & -0.29 & -0.03 & 0.20 & -0.17 & 0.09 & -0.10 & $.852^{\star}$ & 0.58 \\
\hline $\mathrm{DD}$ & & & & & & 1.00 & -0.47 & $1.000^{* *}$ & $-.993^{* *}$ & -0.08 & -0.38 & 0.79 & -0.41 & -0.61 & 0.75 & $.835^{\star}$ & $.822^{\star}$ & 0.19 & -0.19 \\
\hline FS & & & & & & & 1.00 & -0.47 & 0.52 & -0.17 & -0.20 & 0.17 & -0.14 & -0.09 & -0.02 & -0.11 & -0.08 & -0.70 & -0.46 \\
\hline LOF & & & & & & & & 1.00 & $-.993^{\star *}$ & -0.08 & -0.38 & 0.79 & -0.41 & -0.61 & 0.75 & $.835^{\star}$ & $.822^{\star}$ & 0.19 & -0.19 \\
\hline $\mathrm{C}$ & & & & & & & & & 1.00 & -0.01 & 0.35 & -0.75 & 0.38 & 0.61 & -0.73 & -0.79 & -0.80 & $\mathrm{Be}$ & 0.11 \\
\hline $\mathrm{T}$ & & & & & & & & & & 1.00 & 0.60 & -0.18 & 0.62 & 0.14 & -0.09 & -0.49 & -0.16 & -0.12 & 0.10 \\
\hline $\mathrm{Rf}$ & & & & & & & & & & & 1.00 & -0.56 & $.998^{\star *}$ & $.839^{\star}$ & -0.73 & -0.78 & -0.70 & -0.24 & -0.15 \\
\hline IF & & & & & & & & & & & & 1.00 & -0.55 & -0.75 & $.820^{\star}$ & $.851^{\star}$ & $.859^{\star}$ & -0.27 & -0.52 \\
\hline ER & & & & & & & & & & & & & 1.00 & $.832^{\star}$ & -0.73 & -0.79 & -0.71 & -0.28 & -0.17 \\
\hline CR & & & & & & & & & & & & & & 1.00 & $-.965^{\star *}$ & -0.81 & -0.92 & -0.09 & -0.03 \\
\hline $\mathrm{BH}$ & & & & & & & & & & & & & & & 1.00 & 0.86 & 0.98 & -0.01 & -0.13 \\
\hline $\mathrm{RH}$ & & & & & & & & & & & & & & & & 1.00 & 0.92 & 0.09 & -0.23 \\
\hline $\mathrm{RN}$ & & & & & & & & & & & & & & & & & 1.00 & -0.01 & -0.20 \\
\hline $\mathrm{RB}$ & & & & & & & & & & & & & & & & & & 1.00 & $.87^{\star}$ \\
\hline $\mathrm{RL}$ & & & & & & & & & & & & & & & & & & & 1.00 \\
\hline
\end{tabular}




\subsection{Interpretation}

3.3.1 Morphometric vs hydrological properties

Two morphometric parameters (area and total stream length) show a strong coefficient correlation (greater than $>0.8$ ) with some indicators of daily discharge data (i.e., mean, StDEv, Var, Kurtosis and maximal daily discharge). It is well known that a greater area and number of streams inside a watershed will generate more flow. Other morphometric parameters such as texture ratio $(\mathrm{T})$ and elongation ratio (Re) have a moderate correlation with the hydrological property indicators. It can be see in Table 12.

Table 12. Coefficient correlation between morphometric and hydrological parameters

\begin{tabular}{|c|c|c|c|c|c|c|c|c|c|c|}
\hline & & & & $\mathrm{Hyc}$ & logical & perties & & & & \\
\hline & Mean & & $\stackrel{\text { ॠ }}{\stackrel{\Sigma}{\Sigma}}$ & 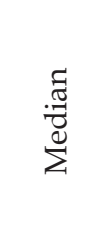 & $\begin{array}{l}\vec{े} \\
\vec{\theta} \\
\tilde{\omega}\end{array}$ & సี & $\begin{array}{l}3 \\
\text { un } \\
\text { w }\end{array}$ & 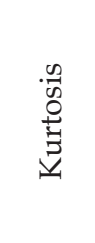 & $\stackrel{\text { a }}{\sum^{\pi}}$ & 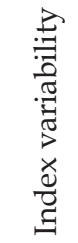 \\
\hline & & & Med & StDev & Var & Skw & $\mathrm{Ku}$ & Max & Ivar & \\
\hline & Area & A & $.871^{*}$ & .567 & $.981^{* *}$ & $.982 * *$ & .604 & $.873^{*}$ & $.984^{* *}$ & .060 \\
\hline & Total stream length & $\mathrm{TLu}$ & $.885^{*}$ & .608 & $.968^{* *}$ & $.997^{* *}$ & .550 & $.819^{*}$ & $.981^{* *}$ & .183 \\
\hline & Bifurication ratio & $\mathrm{Rb}$ & -.445 & -.522 & -.358 & -.214 & -.652 & -.513 & -.273 & -.313 \\
\hline & $\begin{array}{l}\text { Mean stream } \\
\text { length }\end{array}$ & Lsm & .446 & .536 & .282 & .337 & .084 & .217 & .347 & .517 \\
\hline & Stream length ratio & $\mathrm{Rl}$ & -.207 & -.225 & -.102 & -.234 & .548 & -.333 & -.263 & -.085 \\
\hline छ్ & Infiltration Index & IF & -.438 & -.365 & -.405 & -.354 & -.249 & -.599 & -.453 & .110 \\
\hline$\frac{\pi}{2}$ & Basin Relief & $\mathrm{Bh}$ & -.123 & -.191 & -.065 & .101 & -.442 & -.299 & -.016 & .121 \\
\hline छ్ & Relief Ratio & $\mathrm{Rh}$ & -.477 & -.200 & -.646 & -.512 & -.738 & -.668 & -.577 & .381 \\
\hline है & $\begin{array}{l}\text { Ruggedness } \\
\text { Number }\end{array}$ & $\mathrm{Rn}$ & -.471 & -.236 & -.604 & -.463 & -.719 & -.668 & -.541 & .341 \\
\hline & Drainage Density & Dd & -.138 & .049 & -.277 & -.131 & -.445 & -.465 & -.227 & .570 \\
\hline & Stream Frequency & Fs & -.476 & -.458 & -.385 & -.381 & -.123 & -.552 & -.464 & -.080 \\
\hline & Texture Ratio & $\mathrm{T}$ & .407 & .127 & .616 & .509 & .798 & .432 & .491 & -.186 \\
\hline & Form Factor & Rf & -.354 & -.354 & -.337 & -.253 & -.459 & -.426 & -.269 & -.212 \\
\hline & Circulation Ratio & Rc & .083 & .237 & -.044 & -.195 & .307 & .258 & -.071 & -.006 \\
\hline & Elongation Ratio & $\operatorname{Re}$ & .445 & .661 & .204 & .107 & .339 & .488 & .220 & .434 \\
\hline & $\begin{array}{l}\text { Length of } \\
\text { Overland Flow }\end{array}$ & Lof & -.151 & .038 & -.290 & -.145 & -.450 & -.474 & -.241 & .564 \\
\hline & $\begin{array}{l}\text { Constant Channel } \\
\text { Maintenance }\end{array}$ & C & .070 & -.123 & .225 & .080 & .406 & .410 & .172 & -.624 \\
\hline & Basin Shape & Bs & -.525 & -.642 & -.356 & -.244 & -.500 & -.565 & -.352 & -.317 \\
\hline & $\begin{array}{l}\text { Compactness } \\
\text { Constant }\end{array}$ & Cc & -.764 & -.531 & $-.845^{*}$ & -.749 & -.769 & $-.862^{*}$ & -.811 & .063 \\
\hline
\end{tabular}


Other morphometric parameters, such as Lsm, $\mathrm{Rh}, \mathrm{Rn}, \mathrm{Dd}, \mathrm{Re}$ and Lof, have a fair correlation with flooding events, as represented by the index of variability.

\section{Conclusion}

Variability in the hydrological properties described using discharge and rainfall data exists amongst the watersheds. The variability is relatively different or similar, depending on the criteria. It is also shown by the watershed morphometric parameters. Quantitative measurement (or calculation) of this variability can help us to gain more understanding of nature (water resources), knowledge which will useful for us in managing our water resources better.

\section{Acknowledgements}

The work is part of a research grant founded by DRPM Research Grant ( 2017 2018). The hydrological data were provided by the Water Resources Agency (Dinas Pengairan Provinsi Jawa Timur). Many thanks to the students (Ega Wiratama, Bobby Teguh, Cardi Ardiasyah, Yuski Ali) and all the partners ( Dinas PU Pengairan Provinsi) who contributed in the completion of this publication.

\section{References}

Castellarin, A. (2014). Regional prediction of flow-duration curves using a three-dimensional kriging. JOURNAL OF HYDROLOGY, 513, 179-191. https://doi.org/10.1016/j.jhydrol.2014.03.050

Conrad, O., Bechtel, B., Bock, M., Dietrich, H., Fischer, E., Gerlitz, L., ... Analyses, A. G. (2015). System for Automated Geoscientific Analyses ( SAGA ) v . 2 . 1 . 4, 2271-2312. https://doi. org/10.5194/gmdd-8-2271-2015

Guth, P. L. (2011). Drainage basin morphometry: a global snapshot from the shuttle radar topography mission. Hydrology and Earth System Sciences, 15(7), 2091-2099. https:/ / doi. org/10.5194/hess-15-2091-2011

Gordon, N. D., McMahon, T. A., Finlayson, B. L., Gippel, C. J., \& Nathan, R. J. (2004). Stream hydrology: an introduction for ecologists. John Wiley and Sons.

HERMINGLER, K. R., KUMAR, P., \& FOUFOULA-GEORGIOU, E. (1993). On the use of digital elevation model data for Hortonian and fractal analyses of channel networks. Wat. Resour. Res., 29, 2599-2613.

Horton, R. E. (1933). The role of infiltration in the hydrologic cycle. Trans.Am.Geophys.Union., 14 : 446-6.

Horton, \& Robert, E. (1945). Geological Society of America Bulletin EROSIONAL DEVELOPMENT OF STREAMS AND THEIR DRAINAGE BASINS ; HYDROPHYSICAL APPROACH TO QUANTITATIVE MORPHOLOGY. https:/ / doi.org/10.1130/0016-7606(1945)56

Indarto, I., Wahyuningsih, S., Usman, F., \& Rohman, L. (2009). Pembuatan jaringan sungai dan karakteristik topografi DAS dari DEM-Jatim. Media Teknik Sipil.

Khare, D., Mondal, A., \& Mishra, P. K. (2014). Morphometric Analysis for Prioritization using Remote Sensing and GIS Techniques in a Hilly Catchment in the State of Uttarakhand , India, 7(October), 1650-1662.

Lindsay, J. B. (2005). The Terrain Analysis System: a tool for hydro-geomorphic applications. Hydrological Processes, 19(5), 1123-1130. https:/ / doi.org/10.1002/hyp.5818

Lindsay, J. B. (2016). The practice of DEM stream burning revisited. Earth Surface Processes and Landforms, 41(5), 658-668. https:/ / doi.org/10.1002/esp.3888 
Marsh, N. (2003). www.toolkit.net.au/rap, (November).

McMillan, H., Montanari, A., Cudennec, C., Savenije, H., Kreibich, H., Krueger, T., ... Xia, J. (2016). Panta Rhei 2013-2015: global perspectives on hydrology, society and change. Hydrological Sciences Journal, 1-18. https://doi.org/10.1080/02626667.2016.1159308

Meshram, S. G., \& Sharma, S. K. (2015). Prioritization of watershed through morphometric parameters: a PCA-based approach. Applied Water Science, 1-15. https://doi.org/10.1007/ s13201-015-0332-9

Miller, S. L. (1953). A production of amino acids under possible primitive earth conditions. Science, 117(3046), 528-529.

Pallard, B., Castellarin, A., \& Montanari, A. (2009). Sciences A look at the links between drainage density and flood statistics, 1019-1029.

Pande, C. B., \& Moharir, K. (2015). GIS based quantitative morphometric analysis and its consequences: a case study from Shanur River Basin, Maharashtra India. Applied Water Science, 1-11. https:/ / doi.org/10.1007/s13201-015-0298-7

Rai, P. K., Mohan, K., Mishra, S., Ahmad, A., \& Mishra, V. N. (2014). A GIS-based approach in drainage morphometric analysis of Kanhar River Basin, India. Applied Water Science. https:/ / doi.org/10.1007/s13201-014-0238-y

Schumm, S. A. (1956). Evolution of drainage systems and slopes in badlands at Perth Amboy, New Jersey. Geological society of America bulletin, 67(5), 597-646.

Singh, N., \& Singh, K. K. (2014). Geomorphological analysis and prioritization of sub-watersheds using Snyder's synthetic unit hydrograph method. Applied Water Science, 1-9. https:// doi. org/10.1007/s13201-014-0243-1

Soni, S. (2016). Assessment of morphometric characteristics of Chakrar watershed in Madhya Pradesh India using geospatial technique. Applied Water Science, 1-14. https://doi. org/10.1007/s13201-016-0395-2

Strahler, A. N. (1964). Part II. Quantitative geomorphology of drainage basins and channel networks. Handbook of Applied Hydrology: McGraw-Hill, New York, 4-39.

Tarboton, D. G., Bras, R. L., \& Rodriguez Iturbe, I. (1991). On the extraction of channel networks from digital elevation data. Hydrological processes, 5(1), 81-100.

Taylor, P., Shao, Q., Zhang, L. U., Chen, Y. D., \& Singh, V. P. (2009). A new method for modelling flow duration curves and predicting streamflow regimes under altered land-use conditions / Une nouvelle méthode de modélisation des courbes de débits classés et de prévision des régimes d ' écoulement sous conditions modifiées d, (April 2015), 37-41. https://doi. org/10.1623/hysj.54.3.606

Toth, E. (2013). Catchment classification based on characterisation of streamflow and precipitation time series. Hydrology and Earth System Sciences, 17(3), 1149-1159. https:/ / doi.org/10.5194/ hess-17-1149-2013

Umrikar, B. N. (2016). Morphometric analysis of Andhale watershed, Taluka Mulshi, District Pune, India. Applied Water Science, 1-13. https:/ / doi.org/10.1007/s13201-016-0390-7 